\title{
Path Dependence, Coalitions and Interlinked Networks: Legislating Carbon Markets in the Face of Financial Crisis
}

\author{
Janelle Knox-Hayes, Centre for Employment, Work and Finance, Oxford University \\ Centre for the Environment, South Parks Rd., Oxford OX1 3QY, UK \\ Contact. Janelle.knox@ouce.ox.ac.uk
}

\begin{abstract}
This article explores the development of carbon emissions markets through analysis policy formation in the United States. Whether the markets can be developed and operate quickly enough to have an impact in mitigating greenhouse gas production will be determined in large part by how well-designed and stringent the emissions markets are. In addition to the political challenges, the carbon emissions markets now must be developed in the face of financial crisis. The conditions surrounding the development of these markets raise doubt as to whether carbon emissions markets can be successfully designed. It raises the question: are markets inevitably path-dependent, subject to historical events and driven by socio-cultural activity? Drawing insight from coalition and field stabilization theory, I argue that carbon emission market formation is path dependent, but only to the extent that it is shaped by prior existing conditions and perceptions of civil society. Case studies of policy formation the United States and California legislatures are used to demonstrate process of coalition formation and policy field stabilization. The article suggests that policy formation is a path dependent process structured by equilibrium of the motivations the institutions that build coalition.
\end{abstract}

Keywords: Carbon Markets, Market Development, Path Dependence, Coalition Theory

JEL classifications: D72, D40, P21

Acknowledgements. The author would like to thank the many institutions and individuals who participated in the study and made this research possible. The author would also like to thank Gordon Clark and Jarrod Hayes for helpful comments on the article. Support for this research was provided by the National Science Foundation and the Jack Kent Cooke Foundation. None of the above should be held responsible for errors, omissions or any opinions expressed herein. 


\section{Introduction}

Carbon markets are designed to address the looming global crisis of anthropogenic climate change. These markets are being developed in a number of regions around the world including Europe, North America, and Asia as governance mechanisms to reduce the greenhouse gas emissions that cause climate change. This article explores the development of carbon emissions markets through analysis of policy formation in the United States. Carbon emissions markets trade an intangible, constructed asset: the absence of emissions (Knox-Hayes, 2008). Everything from the commodity that is traded to the structure of the markets to the rules that govern its operation must be shaped by policy. The history of the development of carbon markets must be understood from the history of climate policy.

When the Kyoto Protocol was first initiated by the United States in the early 1990s European leaders favored a carbon tax over a market as the mechanism to control greenhouse gas emissions. After ten years of deadlock trying to pass a carbon tax, and withdrawal of the United States from the Protocol, the European Commission accepted the use of a market as a necessary compromise to keep the protocol alive (Watanabe \& Robinson, 2005; Hasselknippe, 2003). The tax had been unsuccessful because it takes one member state to block a tax while a majority was required to block the development of a market. The European Commission members shortly thereafter began working to pass the EU ETS into law (Hansjürgens, 2005; Watanabe \& Robinson, 2005). Within three years the European Union had established one of the world's largest and most successful emissions trading schemes. Under the EU ETS, compliance parties must demonstrate emissions reductions or trade either European Union Allowances (EUAs) or Certified Emissions Reductions (CERs) to meet compliance (Watanabe \& Robinson, 2005). ${ }^{1}$ Due to the success and determination of the European Union, Russia ratified the Protocol and it came into effect on February 16, 2005.

In response to both the withdrawal of the Bush Administration from the Kyoto Protocol and the political success of the EU ETS, a number of regulatory and voluntary market initiatives have developed on the regional and national level in the United States. The Northeastern States are developing the Regional Greenhouse Gas Initiative; California has established a trading initiative under AB 32: Global Warming Solutions Act and several bills including the Lieberman-Warner bill have been introduced in the House and Senate to create a nationwide cap and trade system. Carbon markets differ from other markets in terms of the scope of government involvement - the commodity of exchange is a regulatory creation and emissions reductions are registered and verified by government. Carbon markets are additionally financial markets built around products without a tangible underlying. Nevertheless, carbon emissions trade like other commodities (Knox-Hayes, Forthcoming 2009; Capoor \& Ambrosi, 2008; Hamilton et al., 2007).

Whether these markets can be developed and operate quickly enough to have an impact in mitigating greenhouse gas production will be determined in large part by how well-designed and how stringent the emissions markets are. Meanwhile the urgency in terms of political and economic awareness and scientific concern to address climate change is growing (IPCC. et al., 2007; Stern et al., 2006). Further complicating matters, carbon emissions markets now must be developed in the face of financial crisis. The conditions surrounding the development of these

\footnotetext{
${ }^{1}$ It should be noted that the market for trading emissions is also growing in other areas such as Japan and Australia, and that UNFCCC CERs are produced through the Clean Development Mechanism (CDM) around the globe (Carr \& Rosembuj, 2007). However, for reasons of scope, the focus of this article is the trade and financialization of carbon emissions reduction credits in the United States and Europe.
} 
markets raise doubt as to whether carbon emissions markets can be successfully designed according to the strictures of economic and market theory. Is the design of markets inevitably path dependent, subject to historical events and driven by socio-cultural activity? The question is of significance not only to the carbon markets currently being developed but also to economic systems being developing in real world, chaotic environments.

I argue that carbon market formation and design is constrained by path dependence. In other words market design reflects the will of civil society, but tempered through the use of institutions to intermediate social conflict and achieve consensus in the negotiation of policy. Here design and context interact. The desire of civil society to enact a carbon market implicitly and explicitly relies on economic and market theory to chart the appropriate policy response. However, that policy response is mediated through social and governmental institutions shaped by a unique historical process. Thus, despite similar social demands and theoretical foundations, polities with differing social and governmental institutional contexts will more often than not produce very different policy responses.

The key to understanding the path dependence of markets is therefore to understand the political processes that shape the market. As will be demonstrated here, in the United States legislature this process is one of coalition formation. Social coalitions are needed to stabilize society-wide conflicts of interest over policy formation. The article suggests that policy formation is a path dependent process structured by the activities of the institutions that build coalition. The argument shares in style with the European politics tradition in that it explores specific, real-world empirical cases. However, in adapting from and blending concepts with field stabilization theory from management studies, it also shares with the game theoretical tradition in that it produces a model which could be replicated, mathematically refined, and tested against other cases.

The arguments of the article are supported by the use of cases studies with market institutions and close dialogue, interviews guided by a pre-determined set of questions and conducted on a confidential basis with no citation rights (Clark, 1998). Analysis of interviews and online documents is used to construct two case studies of the climate policy formation process in the United States, 1 ) at the national level with the attempt to pass America's Climate Security Act (the Lieberman-Warner bill), 2) at the state level with the passage of the California Global Warming Solutions Act (AB 32). A map of the political field that underpins climate policy is constructed from the case studies. A model is developed to show how the policy action is negotiated through coalition formation among conflicting interest groups. Coalition formation is a necessary component of decision making in active democracies. The process of negotiating policy reflects the structure of the underlying interests in the democracy. Furthermore, coalition formation carries weight overtime and structures future policy with path dependent inertia.

This article proceeds in five sections. Section 2 examines several key literatures, looking first at the view of market design and path dependence, then exploring coalition formation and field stabilization, before suggesting a new framework for understanding the U.S. legislative process. Section 3 provides an overview of the methodology used to map the path dependence of coalition formation. Section 4 analyzes the development and political process of the Lieberman-Warner Bill, America's Climate Security Act. Section 5 contrasts this with the passage of AB 32: California's Global Warming Solutions Act. Section 6 concludes by suggesting implications and applications for the use of the developed path dependence model. 


\section{Path Dependence and Coalition Theory}

One of the key questions of economic geography regards the production of markets and the degree to which they can be designed or are historically contingent. The question to a certain extent forecasts the likely success of a designed carbon market. ${ }^{2}$ If the market is a more or less pure product of theoretical or political design, can it successfully be accepted and operate within different contingencies? The problem becomes particularly important when considering the ability of the carbon market to operate as an international conglomerate of independent regional structures. Path dependence is a concept of growing importance in economic geography, but the term is still lacking in clarity, and there is ongoing debate in the literature regarding the role of path dependence in structuring markets (for a comprehensive review see Martin \& Sunley, 2006).

Markets and particularly carbon markets are political products; political support plays a critical role in market success or failure (Liverman, Forthcoming). States play an active role in controlling and regulating markets, and likewise have the power to design and manage market structures (Aglietta \& Breton, 2001). To the extent that markets are constructed of legal frameworks and composed of institutions that inform their structure and rules of operation, they must be at least in part designed by political agents (Fligstein, 1996). Yet the literature also indicates that markets, like other institutions, are the product of path dependence or historical events that have long-run cumulative consequences on economic agencies and activities (Martin \& Sunley, 2006; Roe, 2006). Institutions, such as markets, are the 'carriers of history' and they have evolved into their present forms to satisfy some important social purpose (David, 1994). Path dependence is also to a certain extent the product of agglomerated information and human agency, rather than geopolitical events (Porteous, 1999). Historical events are shaped by actors in systems and in particular by the technological, economic and institutional changes that actors make.

The history and geography of markets are thus contingent on the actions and interests of economic agents (David, 2007; Clark, 2002). To some extent financial markets may even price path dependence, attributing the costs and benefits of such historical commitments to market agents in ways that may put in play the virtues of their home locations (Clark \& Wojcik, 2007). The notion of an interactive path dependence suggests that most if not all institutions are the outcome of political and social conflicts that are embedded in a specific society for a given period of time (Boyer, 2005). The institutions that govern a capitalist economy combine a variety of coordinating entities including the state, market actors, communities, networks, and private organizations. The interaction of these agents can produce systems of path dependence (Bassanini \& Dosi, 2001). Although, institutions exhibit large sunk costs and increasing returns (supporting path dependence), institutions constantly co-evolve with technologies and are shaped by human design, or at least response (Glasmeier, 2000). In effect, markets may be a product of interactive systems of path dependence, which are contextual to a particular environment and set of historical events but also impacted by relationships of political, social and economic actors.

The literature reflects ongoing debates as to whether markets can be designed or are constrained by some form of path dependence. This article seeks to add insight to this debate by informing the nature of market path dependence. The carbon markets are the product of both

\footnotetext{
${ }^{2}$ From this point on, I use the word 'design' to indicate efforts to construct the carbon market according to the structures of economic and market theory divorced from the social and historical milieu in which the market is to be constructed.
} 
design and path dependence, in the sense that they are shaped by political and economic agents, and yet constrained by the path of historical negotiation among these agents. Carbon markets were in the first instant a product of design, derived from the theories of Ronald Coase and John Dales, and modeled after the successful Sulfur Dioxide cap and trading market in the United States (Dales, 2002; Coase, 1968). However, path dependence is an important component underpinning their development. This article will in part seek to elucidate the relationship between design and path dependence, and the implications this has for the development and success of the carbon markets. In order to understand the nature of design and path dependence in market construction, it is necessary to understand the political processes which first build the markets. As this article will demonstrate, the policy process of market development in democracies is a process of coalition formation. History matters, but path dependence is not accidental; it is negotiated among societal actors. The mechanisms of path dependence in politics are tied to the structuring of coalitions. We therefore turn our attention to coalition theory.

Coalition theory deals with conditions for coordination and cooperation in situations involving three or more actors with conflicting preferences (Elgstrom et al., 2001). Two general fields of coalition theory have developed, a European politics tradition and a game theoretic tradition (Laver \& Schofield, 1998). The European politics tradition addresses coalition theory with empirical attempts to fit the experience of coalition formation in the European parliamentary system to an inductively derived theory. In contrast, game theoretical coalition theorists have adapted approaches from William Riker's seminal work, which treats the politics of coalition as a constant sum game played for the fixed price of holding office (Riker, 1962). The two traditions have different strengths and weaknesses. Game theoretic studies have mostly been tested on U.S. university campuses and have developed in some isolation to the real political world, and as such suffer from a failure to understand country specific context (Budge \& Keman, 1990; von Beyme, 1983). Studies in the European politics tradition often focus on detailed cases and have trouble replicating the generalizability of game theoretic approaches. The contrasting strengths of both approaches suggest there may be significant merit in trying to combine them. This section of the article highlights some of the sympathetic understandings of coalition theory in both traditions; the next section proposes a model that combines the approaches.

Stable democracy requires the resolution of conflict; the democratic process is a means of channeling or structuring political, social and economic conflict (Lipset, 1963). The legislative process is the mechanism of containing conflict and preserving political consensus (Marks \& Diamond, 1992; Wallace, 1990). Institutions are important for representing and directing the desires of society and can negotiate acceptable and feasible agreements between conflicting interests (Colomer, 2002; Olsen, 1991; de Swaan, 1973). Institutions affect both the perceived incentives of participants and the structure of negotiations (Ecchia \& Mariotti, 1998; Keman, 1997). Institutions interact with the legislative process to balance out the conflicting interests of societal actors who each have something at stake in the outcome of climate policy. In democracies, political balance is stabilized through the establishment of coalitions among the organizations that represent society's interests (de Swaan, 1973).

The key to a coalition is that it must have enough members to achieve a critical mass. Since the object of a coalition is to win a policy objective or majority a vote, once a coalition achieves a certain minimal winning size it does not actively seek additional members (Acemoglu et al., 2006; Riker, 1962). Coalitions based on issue-specific interests bridge sectoral boundaries and challenge notions of the minimum winning coalition hypothesis (Kriesi et al., 2006; Spence, 
1995). In cases of broad social interest, coalition formation is a means to look for broad agreement by persuading outliers to shift their positions closer to the center of policy; unanimity is not necessary (Nugent, 1999; Wallace, 1996). Although the struggle for consensus is usually an obstacle to implement efficient policy solutions, in the context of global public goods it can foster cooperation since it puts more pressure on countries to coordinate and adopt a long term view (Finus, 2003; Ecchia \& Mariotti, 1998). For climate policy formation this is particularly important because for pass climate policy the minimal winning coalition is virtually society wide. It would not be possible to achieve consensus among the myriad interests at stake in climate policy. Rather, the winning coalition is built by gradually shifting the weight of each interest's position closer to center equilibrium structured between all of these interests.

Furthermore, policy is not made among political actors exclusively. Whether through lobbying, or direct involvement in the process, a host of organizations representing civil society, exert their will (Warleigh, 2000). The political environment might be described by corporatism - a term which refers to a political or economic system in which power is shared by civic assemblies that represent economic, industrial, agrarian, social, cultural, and/or professional groups (Pennings, 1997). To some extent all political systems are corporatist; corporatism can certainly be found in the U.S. legislative process under consideration here. Corporatism is a strategy that institutionalizes pathways of socioeconomic conflict resolution by means of consultation and negotiation among representatives of labor, employers and government. This arrangement shapes the political room to maneuver of all actors involved (Woldendorp, 1997). The representation of civil society through interest groups has an impact in shaping policy in a field of conflict. In order to pass policy, a minimum-winning coalition must be formed across the societal public and private interests represented among these organizations.

The structure of policy coalitions raises an important question: are political alliances stable — possibly reflecting core ideological agreements-or do they shift from issue to issue? I argue here coalition formation is stable, such that an established coalition has inertia and can lead to the passage of legislation more quickly time after time. This claim indicates that the legislative process is embedded or path dependent. Current legislation relies on the path previous legislation has taken because the basis for agreement has already been constructed; current legislation relies on previously successful policy (and political) framings. Once a model for policy or coalition formation has been established, subsequent models follow the same approach. To understand this process we turn our attention to neo-Gramscian perspectives on hegemony formation.

\subsection{A Neo-Gramscian Approach}

What is lacking in both European politics and game theoretic coalition theories is a more detailed understanding of the influence of societal actors in coalition formation and the effects these have on the construction of policy. In order to understand these effects, institutional theory can add insight into the process of how institutions affect coalition formation, particularly at the Congressional committee level. The neo-Gramscian framework developed by Levy and Egan (2003) to understand how corporations affect policy retains considerable theoretical traction for analyzing the dynamics of contemporary political contests (Finus, 2003). While Gramsci's work focused primarily on European state politics, he was also aware of the interplay of forces at international, national, and regional levels (Levy \& Egan, 2003). As demonstrated by Levy and Egan, field-level politics can be viewed as a contested process of assembling a historical or 
policy block. The establishment of hegemonic coalition is the equivalent to the process of field stabilization in institutional theory (Levy \& Newell, 2005).

To stabilize a field of conflict, actors seek to build coalitions of firms, governmental agencies, NGOs, and intellectuals who can establish policies, norms, and institutions that structure the field in particular ways. This is true of policy areas regardless of whether the action is driven by private organizations such as large business groups or by political committees trying to achieve societal consensus. As recognized in coalition theory, coalitions are necessary because large organizations are generally unable to dominate a field purely by virtue of brute economic or political power. Instead, control over a field rests on consent from a broader group of societal actors. Field stabilization, or hegemony, depends on an alignment of forces capable of reproducing the field (Levy \& Newell, 2005). In other words, a policy outcome depends on a winning coalition, not only among policy actors, but among society-wide institutions. This is because economic institutions are ultimately embedded in broader political structures (Fligstein, 2001; Granovetter, 1985).

Organizational fields become centers of debates in which competing interests negotiate over issue interpretation (Hillman \& Hitt, 1999). Climate policy is likewise negotiated in a field of debate, between a number of private and public institutions, to interpret and prescribe policy outcomes. The broader the impact of the policy, the broader the scope of the coalition required to stabilize the field of conflict. The stabilization only occurs when a winning number of the interests affected by the policy are satisfied; for broader policies, the affected interests are greater. Climate policy touches on social and economic issues of such a large scope that it is embedded in society wide conflict. At issue is the location of power. Levy and Egan's neoGramscian approach sees power as a strategic conception. Power is not located in resource dependencies or in the discursive framing of issues, but rather in the historical bloc of political field stabilization. It is embedded in the specific alignment of economic, ideological, and organizational forces which stabilize a field of conflict. Power to direct the social and economic activities relating to climate is ultimately held in the structure of the stabilizing climate coalition.

When combined with coalition theory, the neo-Gramscian approach suggests that policy formation is a form of field stabilization. The formation of a coalition to stabilize societal conflict, as demonstrated by a policy outcome, has an incredible amount of inertia. Coalitions define what issues are significant and how to address them. Furthermore, the negotiation of this stabilization and its outcome are ultimately path dependent. Institutional structures can effect change in the field stabilization, but they are simultaneously being constructed and constrained by the conditions of the policy field. Coalition formation or coalition movement can thereby have a profound impact in shifting the bases of political parties (Manza \& Brooks, 1999). The formation of climate policy is shaped by stabilizing a field of conflict between relevant political, economic and social actors, but it in turn moves the position of these actors.

Building from the neo-Gramscian understanding of policy formation, this article combines the European politics and game theoretic approaches to develop a theoretical model to analyze the formation of climate policy as a form of field stabilization. Although the empirical tests of the European politics model are most often applied to the parliamentary system in Europe, the theory also holds validity for the legislative process in the United States (Mèuller \& Strom, 1999; Laver \& Schofield, 1998). Sharing in the European case-based empirical tradition, the model is built from two case studies of attempts to develop climate policy in the United States. The approach used here also shares in the tradition of Castles and Mair (1984) by applying a version of the Delphic technique. This is done by explicitly asking a wide range of 
specialists to provide information about the policy positions of the actors. The policy field and position of institutional interests is ascertained from interviews with these experts and mapped. The map or model that is constructed is built qualitatively out of the insights gathered from policy and other institutional experts. Nevertheless, the model also lends itself to inquiry using game theoretical techniques and could be mathematically modeled and tested.

\section{Methodology}

The basis for field stabilized or path dependent coalition formation will be studied with two case studies. ${ }^{3}$ The first examines the attempt to pass the Lieberman-Warner Bill (Senate bill 2191—“America's Climate Security Act”) in the United States Senate in the summer of 2008. The bill would have set a limit on the emissions of greenhouse gases, mainly carbon dioxide from the combustion of coal, oil, and natural gas at the national level, and established a nation-wide cap and trade scheme. The second cases analyzes the successful passage of AB 32, California's “Global Warming Solutions Act," which in addition to initiating a host of energy efficiency programs, sets a mandate for California to establish a cap and trade program with the Western Climate Initiative (WCI). Although the Lieberman-Warner bill did not pass, it is a critical case study. The bill has to an extent determined the model of future legislation; the attempt pass was therefore not a failure but rather a link in an already established chain of action, or field stabilization.

Interviews with members of state and federal legislatures, NGOs, industry associations, utilities, legal firms and think tanks were used to map the policy field. Each interview has been qualitatively cross-checked with other interviews to verify the findings. The case study approach is well suited to describe and conceptualize the developing carbon markets and their relationships in space and time (Quattrone, 2006). As with all methodologies, it has drawbacks. In particular, perspectives and experiences of individuals are not always accurate representations of actions or facts (Berry, 2003). However, the triangulation of results confers rigor and credibility to the conceptualization (Strauss \& Corbin, 1998). A key prerequisite for this rigor is access, as only the testimony of key market makers and decision makers will afford an acceptable level of confidence in the findings (Goldstein, 2003). In this study, the cases are built over the course of over 100 interviews conducted with policy makers, experts from banks, brokerages, intermediaries, legal firms, consultancies, and wire services in Washington D.C. San Francisco, Los Angles, London and New York. Owing to the sensitive nature of the issues under discussion, all interlocutors are anonymous.

Interviews were conducted using a semi-structured format with an initial list of 19 questions. The information supporting the structure of the policy field and role of institutions was drawn from several standard interview questions including: What role if any does/has your organization play(ed) in developing carbon legislation? What role if any did/do NGO's or private enterprise play in developing the legislation? What are the challenges of passing the legislation? What steps did/are you take(ing) to pass the legislation? What does your institution see as the advantage or disadvantage of a market approach as opposed to taxes or command and control incentives for emissions reduction? Although the interviews were semi-structured,

\footnotetext{
${ }^{3}$ Although both cases are considered separately, the dynamic tension between them should be noted. California's AB 32 was developed in part to address the failure of the Bush Administration to address climate change and to preempt federal action. The Lieberman-Warner bill was initiated not only to address concerns over climate change, but because of the growing pressure from state and regional schemes such as AB 32. In addition, the broader coalitions of both bills are connected through powerful lobby and interest groups such as The Climate Group.
} 
interlocutors were allowed and encouraged to explore other topics they felt relevant to their carbon related activities. The standard interview format required one-hour, but the interview length varied between 45 minutes and 2 hours depending on participant availability and interest. Detailed notes were taken during the interview. The transcripts were later formatted and uploaded to a data file using NVivo, a software package which assists with data queries and dialogue searches of coded text. Each interview transcript was labeled with the type of institution and position of individual interviewed. Relevant questions were coded into separate nodes, which allowed for the question responses to be grouped (yet remain distinguished with an institution/position label) and analyzed across institution type. The responses were triangulated within and across institution type. While these methods are qualitative, they were rigorously applied and could be replicated in other studies.

Analysis of the interviews was used to map the policy field and determine organization positions. With respect to addressing climate change by reducing greenhouse gases four basic policy options available at both the state and federal level were identified: 1) take no action, 2) use taxes to set a price signal for $\mathrm{CO}_{2}$ and other greenhouse gases, 3) use command and control mechanisms such as energy efficiency standards to reduce greenhouse gas emissions, 4) use a market mechanism (cap and trade) to set an overall quantity and market price of greenhouse gas emissions. A number of hybrid options were also on the table, and the structure of these policy positions was representative of policy choice on two axes, a liberal to conservative response, and public to private response (Diagram 1). Congressional committees establish an initial policy position within the policy field. Active lobbying institutions and interest groups likewise establish initial positions. The process of negotiation and coalition formation to stabilize these interests and achieve a final balance will be demonstrated through the two case studies. Interest group positions were determined through interviews. Although exact positions are not diagramed, for both the Lieberman Warner and AB 32 cases the positions of interest groups are roughly mapped to illustrate the process of field stabilization. ${ }^{4}$

[Insert Diagram 1 here]

\section{Case 1: Carbon Legislation at the National Level}

\subsection{Lieberman Warner}

In June 2006 the Senate voted down the Lieberman-Warner bill. The bill would have mandated a national level cap-and-trade system and brought US targets on cutting emissions roughly in line with the recommendations of international scientists. For many the bill was viewed as a failure. For others it represented progress in the legislative debate over climate change. As I aim to demonstrate here, the attempt to pass Lieberman-Warner was an important step in stabilizing a policy field of conflict. Involved in the negotiation over the bill were not just political groups, but a host of private and public groups including NGOs, industry groups and labor unions which represent the varied interests of society. Lieberman Warner was an important step in building a coalition for climate policy. As I aim to demonstrate here, although

\footnotetext{
${ }^{4}$ Although this model is purely illustrative, it would be possible to develop metrics, perhaps using survey techniques, to determine exact positions of organizations in the policy field. Additionally, metrics to determine relative gravitational weights for each interest group could be developed. The field stabilization process could then be mathematically modeled.
} 
the bill did not pass, it has established an initial coalition, shifted the policy field and set the inertia for future climate legislation.

Prior to the development of the Lieberman-Warner bill several other bills were put forward in the House and Senate, without success beyond the committee level. One of the most notable pieces of legislation was introduced to the Senate in 2005 by Senators McCain and Lieberman. The bill proposed to reduce six greenhouse gases covered under the Kyoto Protocol starting in 2010. The program would have capped emissions on affected facilities’ 2000 emissions (for any entity that emits from a single facility more than 10,000 metric tons of greenhouse gases (carbon dioxide equivalent), and would have been implemented with an expansive allowance trading program that would allow cross-sector trading, carbon sequestration, and limited offset use from foreign sources. In June 2005, the McCain-Lieberman bill was debated on the Senate floor and defeated by a 38 yes to 60 no vote. Although the bill was passed, its success in getting past committee and to the floor played an important role in generating awareness and inertia for climate legislation.

The McCain Lieberman bill framed ensuing climate policy efforts and fixed the policy field. Consequently, when the Lieberman-Warner bill was put forward in an effort to take advantage of growing public awareness of the climate change issue, it was significantly shaped by the legacy of McCain Lieberman. By 2006 awareness of the concerns posed by climate change was growing. A number of events had pushed the issue into the public spotlight, including the devastation of Hurricane Katrina, the growing certainty and publicity of the IPCC reports, and Al Gore's award winning film An Inconvenient Truth and his subsequent Nobel Peace Prize. The Stern Review, which put an economic cost of climate change at up to $20 \%$ of global GDP, also gained attention in the United States (Stern et al., 2006). As highlighted by a number of interlocutors in this study, industry groups and politicians alike were beginning to recognize that some form of climate legislation was inevitable.

As a representation of this shifting field, Lieberman-Warner was successfully passed by the Environment and Public Works Committee in 2007 and was moved to the Senate floor. Despite its initial success, the bill was voted down. Many of the legislative staff that were interviewed suggested that the bill crumbled under its own weight. When the bill was introduced to the Senate Environment and Public Works Committee on May 20, 2008 it was 260 pages in length (Lieberman \& Warner, 2007). By the time it was put to a vote on June 6, 2008 it was over 500 pages in length with amendments. A full overview of the bill is not possible here, but it set more ambitious targets than prior attempted legislation. It would have created a capand-trade system administered by the Environmental Protection Agency, together with an emissions monitoring and reporting system. Offsets from domestic agriculture and forestry could total up to 15 percent of the cap. Another 15 percent may come from international actions, including 10 percent from national-level programs to reduce tropical deforestation. Additionally, emitters would be able to bank and borrow limited amounts of emissions allowances. The scheme would have auctioned credits with reserve price is set by the President between \$22 and \$30 per ton in 2012 and a floor price set by \$10 per ton (NRDC, 2009).

Most of the detail of the bill was dedicated to distributing revenue from the auction of credits to various programs and institutions. By the time of the vote 70 percent of proceeds were dedicated to emission reductions programs outside the cap, while 30 was dedicated for lowincome assistance.

The structure was very similar to McCain-Lieberman, but we wanted to increase the level of detail to get the votes needed...In the end it was too detailed and most of the detail was in the allocation process. We 
still had to generate political momentum by creating programs that were attractive, and we used allocations to buy political support. Part of pushing the bill through the machinery---the subcommittees, the committees and the floor---is getting votes. People whose votes you need, have the right to demand things. This led to the detail of allocation and programs and added to the length of the bill.

-Legislative Assistant to U.S. Senator, September, 2008, Washington D.C.

As this legislative assistant suggests, the distribution of programs and revenue was not a sign of corruption or collusion so much as an honest attempt to manage the many interests at stake, and to garner support. In order to have enough votes to pass the legislation the bill must please the constituencies represented by the Senators conducting the vote. At stake in the passage of climate legislation are a number of issues, as the bill touched on economy-wide operations. The first challenge was one of scale. The United States is composed of a myriad of state and regional interests. The most direct challenge is the fact that different states and regions have different power generation schemes. California and several Northeastern states have decoupled energy provision, which makes their electric industries more competitive. The provision of a nation-wide cap has the potential to adversely affect already inefficient regions more than others (Knight, 2008). In addition to variation in power provision there are regional economies across the United States. The Midwest is still the agricultural center or 'bread basket'. Industry, such as automotive is heavily provisioned in the Northeast. The South, and particularly Texas, is the oil capital of the U.S. In general the South tends to be more conservative and skeptical of environmental provisions.

Interests groups also vary by geography. Environmental NGOs and think tanks tend to headquartered and active in the traditionally more liberal coastal states such as California and New York. Business interests are represented in a number of the financial capitals, particularly New York. The political positioning of these groups represents society-wide conflict of interests over the outcome of climate legislation, and the effects it would have on their constituents. Senators likewise are concerned with and aligned with certain of these interests according to the geographies they direct. As coalition theory suggests, for the Lieberman-Warner bill to succeed it must have build at least a minimum winning coalition amongst these interests. Ultimately, for the bill to be passed, a coalition of these interests needed to be convinced that the benefits of the legislation would outweigh the costs of inaction (unmitigated climate change) or another form of legislation.

We met with over 200 stakeholders before and after the comment period. It was nonstop meetings over several weeks. We were forcing them to get their cards on the table and trying to negotiate the bill through those meetings. -Legislative Assistant to U.S. Senator, September, 2008, Washington D.C.

The weight of Lieberman Warner, both in terms of the size of the bill and the provisions it established, represented an attempt to build a winning coalition among the myriad interest groups it would affect. In order to build coalition the bill attempted to buy support through the multiple and detailed programs its revenue stream provisioned (Lieberman \& Warner, 2008). In other words it tried to establish a winning coalition by positioning itself in equilibrium between the interests it needed to succeed. The offices of senators Lieberman, Warner and Boxer (who chairs the Environment and Public Works Committee) established an initial policy position, but the final outcome was a negotiated process with the interests groups that represent the constituencies needed to pass the vote. The stabilization of conflict is illustrated in Diagram 2. As ascertained from interviews, the relative positioning of interests groups are shown on the 
diagram. These positions are not exact; they are meant purely to illustrate the process. ${ }^{5}$ Industry groups and particularly the utilities were actively lobbying either for no action or for a tax that would send a clear price signal, which would help them to forecast and assess future risks and liabilities. Environmental NGOs held several positions, but mostly supported a mixture of stringent command and control programs, such as efficiency and renewable portfolio standards, and market mechanisms. Powerful coalitions like the International Emissions Trading Association (IETA) supported a market mechanism, and provided detailed recommendations of how this should be structured (IETA, 2009). Several regulatory agencies were in favor of a tax as it is easier to administer and the revenue is more easily controlled. Faith-based groups supported whatever format the legislation took so long as it provided financial assistance to low income people.

\section{[Insert Diagram 2 about Here]}

The field of conflict between these interests is stabilized as the policy negotiation progresses. Interest groups exert pressure on the policy action; the policy action likewise exerts pressure on these interests groups. The strength of the lobby depends on a number of factors, size of the constituencies represented by the group, revenue support, and distance from the policy action etc. The relative strength of these constituencies is represented by the thickness of the vectors (Diagram 2). Additionally, groups that can successfully organize and build coalitions, such as the industry and labor coalitions, exert more gravitational force on the policy outcome by supporting a unified position. Diagram 3 illustrates the movement of both the policy action and the policy position of interests groups involved in the process. Although the legislative process has shifted the field towards a market based solution with command and control programs (energy efficiency etc), the position did not move far enough away from the tax and no action options for the legislation to be passed. Nevertheless, as Diagram 4 illustrates, the policy process, as represented by the movement of the bill through committee and to the floor, shifted the field and has created inertia for future climate legislation. The sum movement of each of the interests groups and policy committees involved has been towards a combined market-command and control approach. Future legislation will utilize this inertia.

[Insert Diagram 3 and 4 about here]

\subsection{Moving Forward with Additional Committee Support}

Congressional committees are crucial to the operation of coalitions in US legislative politics. The political systems is not a pure majority rule system, because it involve hierarchies of committees (Schofield, 1986). Committees and the other institutional mechanisms of influence are available to legislators as a means to shape policy, whether they are in or out of office (Laver \& Schofield, 1998). The operation of the congressional committee system could easily impose a bargaining equilibrium upon an otherwise unstable situation (Shepsle, 1979). Congressional committees control the legislative agenda and have jurisdiction through specialization, such that each committee deals with only a single policy dimension. Since policy questions are considered by committee, the committee has the power to set the agenda and recommend action on this matter to the legislature. Since modifications to a bill be made only

\footnotetext{
${ }^{5}$ In addition, not all of the relevant interest groups are diagramed, only those that played the most active role.
} 
with policy matters that are germane to a particular committee, the key decisions are only taken on one dimension at a time (Shepsle, 1979). Lieberman-Warner struggled against nature of the committee system. It was put forward by the environment and public works committee, but the bill could not succeed with this dimension alone. Climate change is not a one-dimensional policy choice; there are several relevant committees to the policy action and therefore ultimately equilibrium is a balance between the five committees needed to support the legislation and their relevant areas of jurisdiction. As such, the scope of institutional actors that must be negotiated and incorporated into the coalition is far greater, than if the policy fit within the jurisdiction of one committee. With climate policy, the scope of committee involvement reflects the fact that there is a society-wide balance of power to be decided in structuring the governance of a low carbon economy.

As Diagram 4 illustrates, the field has shifted and the inertia of the stabilization will move policy towards a combined market and command and control approach. In addition, to shifting the policy field, the Lieberman-Warner bill generated awareness and garnered support in committees that were missing but necessary to its passage.

\footnotetext{
It was very large for bill written by one committee. Energy bills are long, but written by all the committees of expertise. The committees were complaining not about the length but that they had not written the length. They hadn't brought their expertise to bear on issues that fall under their jurisdictions. There a lot of complexities. The Energy, Finance, and Environment Committees are the main committees needed, but Agriculture and Commerce Committees will write components as well...Most of those senators see if they sit out and wait, they may well be presented with dug-in legislation they cannot influence. They want to participate, because they see the risk or opportunity that this could be passed in the next Congress. So now they want to help shape it. -Legislative Assistant to U.S. Senator, September 2008, Washington D.C.
}

Ultimately the bill did not succeed in establishing legislation. However, it did successfully shift the policy field and create inertia for the next legislation, particularly in the necessary committees which did not participate in Lieberman Warner. Before the vote was passed 10 prominent senators released a letter to Senator Boxer explaining why they could not support Lieberman-Warner as it was drawn up, but dedicating their support to future legislation.

10 Senate offices wrote a letter to Senator Boxer after the vote and said we wouldn't have voted for the legislation, here is why. That group of 10 Senators is continuing to think about what to do. They are 'heartland' offices, and you need that vote. With their constituents, the next legislation will pass. There is coal and farmland and all sorts of important constituencies represented in the heartland. -Member of a Legal firm that consults with Senate Offices, September 2008 Washington D.C.

Getting people to the table and getting people to think about impacts on states and committees is the way to get people engaged in the process and to have an effective bill...We got the support of faith comminutes, businesses, local communities, NGOs, labor unions, even the Conference of Mayors...We got a significant number of labor groups to endorse the bill. We were trying to bring everything together. It is the beginnings of a coalition, not the end of the story. It helped us figure out the roadmap going forward. -Legislative Assistant to U.S. Senator, October 2008, Washington D.C.

The work and effort that was dedicated to Lieberman-Warner is undoubtedly the building block of the next legislation. With the support of the 'heartland' Senators, the missing committees, and a new President, climate legislation is now almost inevitable. However, the real significance of the field stabilization process is that it has built an initial society-wide equilibrium and thereby set the common framework upon which future legislation will be laid. The successfully negotiated components of the bill are unlikely to be renegotiated. What will be 
negotiated are issues of conflict that were not successfully tied in. Over time, the legislation will slowly shift the policy field, and move the coalition closer and closer to the same position. This aspect of field stabilization through coalition formation can perhaps best be illustrated with climate legislation in California.

\section{Case 2: Climate Legislation in California}

\subsection{AB 32: Global Warming Solutions Act}

In contrast to the Lieberman-Warner bill, Assembly Bill 32: “California Global Warming Solution Act of 2006" (AB 32) was only 13 pages in length and passed through the state legislature and was signed into law in a matter of months. The bill, authored by Assembly Speaker Fabian Nuñez and Assembly Member Fran Pavley, commits the state to reducing its greenhouse gas emissions to 1990 levels by 2020. The reduction will be accomplished through an enforceable statewide cap and trade system that will be phased in starting in 2012. AB 32 directs the California Air Resources Board (CARB) to develop appropriate regulations and establish a mandatory reporting system in order to effectively implement the cap (Nuñez \& Pavley, 2006). The bill was signed into law by Governor Arnold Schwarzenegger on September 27, 2006. The California Air Resources Board has since begun to implement a number of energy efficiency programs and to develop the scoping plan that will determine the exact methods by which California will meet its targets. In contrast to the Lieberman-Warner bill, AB 32 was passed into law very quickly, and leaves a large amount of discretion to CARB. The discrepancy between the bills is exemplary of the nature of coalition formation and path dependence over time.

Although the scale of legislation in California is less daunting than at the national level, the quick passage of AB32 can not be explained by suggesting that California is a progressive state with few conflicting interests. California is the most populous state, accounting for fully $12 \%$ of the U.S. population (US Census Bureau, 2009). Stretching half way up the Western Coast of the United States it contains a number of disperse geographies and regional economies, including sizable agricultural activity in the south, technology-oriented activity (Silicon Valley) in the north, and the nation's largest entertainment industry in Los Angeles. In addition, it is the transportation hub of the U.S.: the Ports of Los Angeles and Long Beach account $44 \%$ of all the container goods entering the United States (Villaraigosa, 2007). As a result of these regional geographies, California is composed of a diverse political atmosphere, with a mixture of liberal and conservative regions, a Republican governor and a Democratic State Assembly. There are hundreds of interest groups in California, ranging from the California Bankers Association to the California Farm Bureau Federation. These groups wield considerable power in California, with groups such as labor unions and industry associations that possess a monopoly on a crucial skill or hold special expertise having more leverage than other groups (Culver \& Syer, 1988). As with national legislation, enacting climate policy has required the construction of a winning coalition. The quick passage of AB 32 reflects the fact that this coalition was built and has been stabilized for many years.

To pass a bill in DC or in Sacramento is all about relationships. It's about the coalition...we started few environmental groups and split up tasks. We would meet and try to build on numbers. We had responsibility sharing. We ran it like a campaign and did outreach... If you pass the legislation, it sends a signal to people that there is a market where people can invest. The amount of venture capital support 
pouring into the Bay Area now is incredible...So what started as an environmental issue in 2001 2002, has garnered a lot of business support. -California Policymaker, August 2008, Los Angeles, California

As this policymaker highlights, a strong coalition of interest groups-including business interests-is critical to passing legislation. But once legislation is passed, or in the California case a series of environmental bills, the process builds a momentum of its own. It creates a new culture or institution that carries the intent of the legislation across the economy. In this case, the strong history of environmental legislation in California has driven venture capital into clean technology forward.

\subsection{Coalitions formed on a History of Environmental Legislation in California}

The quick passage of AB 32 is explained by the fact that California had a strong coalition in support of the bill. As ascertained from a number of interviews, the majority of groups supported AB 32 and shared similar policy positions. Diagram 5 illustrates the nature of the coalition that backed AB 32. In contrast to the policy field that negotiated Lieberman Warner, the interests groups are much more closely aligned around the policy action centered on a mixture of command and control and market mechanisms. This position is not where the state originally started. The structure of the field stabilization that passed AB 32 has been constructed over 40 years of policy efforts to improve air and environment quality and energy efficiency (Rosenfeld, 1999). The movement and political inertia of each stabilization (as illustrated in diagram 4) has shifted the equilibrium further and further into the market and command and control response groups. In effect, the structure of the legislation and the remarkable fact that a bill with such impact could be passed with so little detail and so quickly, demonstrates the path dependence of the political process and of each subsequent policy stabilization. Over time the gravitational force of each interests group and the policy actions has pulled the coalition that addresses environment or climate policy closer together.

\section{[Insert Diagram 5 about here]}

California has not always evinced a strong environmental record. In part because of its importance as a transportation hub, the state has a history of clean air problems. The quick passage of AB 32 can be explained by three historical circumstances and sets of events. First, California has been developing legislation to improve the quality of its air, particularly by reducing emissions from automobiles for over 40 years. ${ }^{6}$ This legislation has been a driving force of vehicular emissions standards not only in California, but across the United States. The development of clean air legislation has also led to the establishment of two agencies with jurisdiction over emissions and other air quality standards. The California Air Resources Board (CARB), which conducts research into the causes of air pollution and regulates a number of programs to control pollution from vehicles, was created in 1967 (CARB, 2009). Following on the success of CARB, the California Energy Commission (CEC) was established in 1975, as the primary energy policy and planning agency and with jurisdiction over energy regulation (CEC, 2009). The second significant legislative achievement that has stabilized California's environment policy field was the passage of the Amendments to the Clean Air Act to develop

\footnotetext{
${ }^{6}$ For a full legislative history see (Hanemann, 2007).
} 
emissions standards for new vehicles. This was the first of a series of wavers which has asserted California's independence and allowed it to preempt national standards for everything from fuel economy to energy efficiency.

Finally, for the last twenty years California has been developing legislation to control greenhouse gas emissions (Hanemann, 2008). Assembly member Byron Sher introduced the first climate legislation in 1988 in the form of AB 4420, which called for the compilation of an inventory of GHG emissions from all California sources. In 2000, as a member of the State Senate, Sher introduced SB 1771, a bill which led to the creation of the California Climate Action Registry (CCAR), a non-profit corporation to record and register voluntary GHG emissions. The CCAR is now under consideration as the framework for a national registry, once legislation is in place at the national level. California Assembly member Pavley likewise played a role in developing considerable climate legislation. Most notably, in 2001, she introduced AB 1493, a bill requiring CARB to adopt regulations to reduce GHG emissions by new motor vehicles sold in California. In order for the legislation to be enacted, California needed a waiver from the EPA to preempt national standards to regulate GHG emissions. Under the Bush administration the waiver was denied, and series of legal battles ensued. The matter was finally settled in 2009 by President Obama who directed the EPA to grant the waver. Each step towards building this legislation has required and strengthened a coalition of interests to support the legislation. By the time AB 32 was introduced the framework of this coalition was well established. As one of the senior policy advisors at one of the regulatory bodies stressed:

Everybody was involved in getting the bill passed all groups including industry groups etc. were active. There were remarkably strong business communities of support. California has an active clean technology industry. The government is also very persuasive with industry. -Senior policy advisor, California Regulatory Agency, August 2008, Berkley, California

As with AB 32, most of the legislation has left decision making to the discretion of CARB and CEC. At the national level, garnering support for a bill without sufficient detail outlining every aspect is at best difficult. In California, an incredible amount of trust is left to the technocratic elite of these agencies. In the policy field of energy efficiency or environmental standards, the quick passage of legislation, without the details of enforcement, has become institutionalized. The establishment of agencies like CARB and CEC are to some extents embodiments of the coalitions that have been built to pass environmental legislation. Once these institutions had gained a certain amount of jurisdiction, leaving the structure of regulation to these agencies is now not so much a matter of trust but a matter of normalized procedure. This is not to say that conflict does not arise during negotiation over which agency will have jurisdiction over legislation.

Part of the conflict in establishing AB 32 was determining which agency would be in charge of implementing regulation to reduce of greenhouse gas emissions. Governor Schwarzenegger had initiated the process on June 1, 2005 stating by releasing Executive Order S-3-05, which established that California would reduce its GHG emissions to 80\% below the 1990 level by 2050. The Governor designated the California EPA (under his direct purview) as the lead agency for climate affairs. The State legislature responded by releasing AB 32, to achieve the same targets, but to leave the discretion of implementation to CARB. On Aug 30, 2006 (one day before the legislature would have closed session and halting the progress of the bill until the next legislative session) a compromise was reached and the bill was passed (Hanemann, 2007). Governor Schwarzenegger signed it into law on September 27, 2006. CARB 
would have control over implementation, but to protect business interests the Governor had a 'safety valve' (whereby the cap could be relaxed by the Governor under extraordinary circumstances) written in to the legislation. ${ }^{7}$ As one of the senior legislative advisors suggests, part of the difficulty in establishing which agency has jurisdiction is that climate change is new and extensive:

The Legislature has an important role to play to appropriate the money and have oversight over [the market] and the California Air Resources Board. There are important policy debates on things like cap and trade. The Senate is skeptical of cap and trade. But it has been proven to us as the best way to go. There is both a formal role in the political role, if the government is to go out on a limb. Neither the California Air Resources Board nor the state government has its handle on all of the different aspects of climate change. Other agencies are doing regulation as well. But no one has clearly defined activities. This is a new area of law and regulation and it requires development. -Senior Legislative Assistant, California State Senate, August 2008, Sacramento California

Entrusting the structure of regulation to institutions of jurisdiction also exists at the national level. For example 30 years of legislative work to protect the environment has created a considerable field of jurisdiction for the Environmental Protection Agency. As this article has explored, the mechanisms that explain the development of these institutions and their areas of expertise are coalition formation and policy field stabilization. The process is path dependent. At both the national and state levels, the initial starting conditions and the ambitions of the actors that drive coalition formation direct the development of climate policy (particularly policy to development emissions markets) in a path dependent matter. Although the process has not been explored here, the existence of other regional fields of policy undoubtedly has an influence as well. The existence of climate legislation in the European Union has driven the development of legislation among certain states, which in turn influences the development of legislation at the national level. The path dependence of policy formation suggests that the development of emissions regulation (in the form of both market mechanisms and command and control programs) is inevitable. Both the equilibrium/stabilization of interest groups at the national level and the feed-in from other policy mechanisms are directing the inertia of the policy field towards market mechanisms. Only substantial circumstances could shift the inertia of the policy field from the trajectory it has established.

\subsection{Financial Crisis and the Resolve for a California led Climate Solution}

Circumstances and events can disrupt this momentum and in the process shift the position of an entire field. For example, the occurrence of a catastrophic event such as the Three Mile Island Accident or Chernobyl shifted an entire policy field away from nuclear energy. For climate policy, both significant climatic events (on the scale of Hurricane Katrina) and financial turmoil can have similar effects. A catastrophic climate event, such as another hurricane, or flooding would increase the urgency to address climate change and shift the policy field left towards a quick solution. The current financial crisis should have an impact in either shifting the

\footnotetext{
${ }^{7}$ Although this was the original agreement, the Governor had the last word in the form of Executive Order S-17-06 on October 10, 2006. This Order reaffirms the primacy of the Secretary of the California EPA to lead GHG emission programs, and directs CARB to work with the Secretary of CalEPA to implement AB 32, and in particular to develop a comprehensive market0based compliance program, which permits trading with the EU ETS, RGGI and other jurisdictions (Hanemann, 2007).
} 
field farther up towards a public, command and control response and away from private responses. There are some early indications that the crisis has created a fear of market mechanisms, and yet the impact is not significant enough to shift the field entirely away from markets.

It is difficult to say whether there will be resistance to creating markets, because of the [economic] difficulties we are facing now. That is one of the contexts we will have to operate under, but to say America doesn't believe in markets is an extreme view. We would be a different country if that were the case. We may have fallen off track, but not changed completely. -Legislative Assistant to U.S. Senator, October 2008, Washington D.C.

Nevertheless there are signs of a growing command and control response, with Secretary of State Clinton meeting with Chinese leaders to discuss cooperative government cooperative actions to address climate change (BBC, 2009a). At the press conference she states "It is in our view imperative that the United States and China co-operate on a range of issues from the economy to global climate change to development and so much else." In addition, investing in clean energy initiative seems to be a cornerstone of the Obama Administrations response to the economic downturn (BBC, 2009b)

As Manza and Brooks (1999) suggest, crises or dramatic events can shift the bases of political systems. Indeed the current financial crisis undoubtedly had an effect on the election of President Obama. Among other things his administration represents a dramatic shift in environmental policy. On January 26, 2009, after 8 years of contention with the Bush Administration, he quickly settled the issue of the California EPA waiver to enact AB 1493, and set the tone for the climate policy of the next four years stating:

\footnotetext{
"California has shown bold and bipartisan leadership through its effort to forge 21st century standards and over a dozen states have followed its lead. But instead of serving as a partner Washington stood in their way. This refusal to lead risks the creation of a confusing and patchwork set of standards that hurt the environment and the auto industry. The days of Washington dragging its heels are over. My administration will not deny facts. We will be guided by them. We cannot afford to pass the buck or push the burden on to the states. And t hat is why I'm directing the Environmental Protection Agency to immediately review the denial for the California waver request and determine the best way forward. This will help us create incentives to develop new energy that will make us less dependent on the oil that endangers our security, our economy and our planet” (BBC, 2009b).
}

The actions of the Obama administration will have a profound impact on shaping and progressing climate policy. Whether these actions will be sufficient to address climate change remains to be seen. The financial crisis could have two impacts: 1) it could divert attention from climate crisis and consume political capital in other economic reforms 2) it could be the driving momentum for climate policy, addressing both financial and climate crises with the creation of a New Green Deal, and the quick transition to a low carbon economy. The Obama Administration seems set on the latter, and As President Obama himself suggests this administration is a marked contrast from the last. Yet, it is unreasonable to suggest that President Obama is solely responsible for the momentum now driving climate policy forward. As this article has demonstrated, the inertia and track of that policy had already been set. Indeed, whether or not he would have been as forceful or successful, Senator McCain, the Republican contender for office, likewise supported the development of a cap and trade system. The nature and structure of this system remain to be seen, but it will likely follow in the footsteps of Lieberman-Warner bill, 
adapting its successes, learning from its mistakes, and building on its coalition. Therefore it is reasonable to conclude that markets can be designed, but only to the extent that their design is negotiated among societal wide interests in a political process that is path dependent.

\section{Conclusion}

Whether carbon markets can be cleanly designed or are constrained by path dependence is an important question of policy. This article suggests that coalition formation and policy field stabilization shape policy outcomes, and that the path dependent characteristics of these processes are of significant importance. The establishment of markets (or for that matter other forms of legislation) are constrained by path dependence, but as Clark (2002) and Boyer (2005) suggest, it is interactive path dependence as interests groups interact with each other and the policy process. The passage of legislation depends on the positioning and interaction of interest groups. These interests groups represent the will and broader desire of civil society. Under democracies, field stabilization, in the form of coalition formation sets a development trajectory for policy, a form of path dependence. Field stabilization, and the policy processes that underlie it, generate a policy momentum that uniquely shapes future policy framings and efforts.

The finding here regarding the importance of path dependent processes — embodied in field stabilization and coalition building -in the development of the carbon market has important ramifications for our understandings of the policy process. In short, social scientists can no longer assume that theories are applicable across space, times, and societies. Careful work needs to be done to assure the general applicability of theories. This prescription is particularly trenchant for economic studies, which tend to depend on a crucial set of historically and socially agnostic simplifying assumptions for explanatory leverage. As this article shows, theory alone cannot explain, or predict, the policy outcome of carbon market formation. While the policy options are informed by theory, the actual policy result depends strongly on prior policy efforts, historically and socially contingent coalitions, and the resulting framing of policy possibilities and probabilities.

The Lieberman-Warner and AB32 cases illustrate how path dependence relies on coalition formation. At an initial glance it is stunning that AB32 passed so quickly with so little text while Lieberman Warner took months of negotiation, and with more than 500 pages of detail could not pass the Senate floor. Understanding the underlying conditions and particularly the history of coalition formation in California, built around other clean air legislation, clarifies the situation. The relationship between the cases is also interesting. Legislation in California has long had an impact on the development of legislation at the national level. Indeed the state has been a forerunner of national environmental and energy policy. It is significant that President Obama set the tone of his Administration's climate policy by suggesting it was time for the nation to follow California's lead. The relationship between coalitions at different levels of analysis is not fully explored here but would add further insight into the nature of path dependence.

The findings here suggest that are indeed dynamic feedbacks between policies of different scale. However, future research might in particular investigate the relationship between coalitions of different scale (national, regional, state level) within the same policy system as well as without. The development of an acid rain program in the US fed into the creation of the Kyoto protocol which in turn led to the EU ETS in Europe. When the response was not forthcoming at the federal level, states such as California began initiating their own policies, preempting federal legislation, which is now forthcoming. The nature of these relationships (and 
particularly the coalitions that drive them) at different scales could add considerably to the development of coalition theory, and particularly the path dependence of policy.

The study lays the foundation for investigation into the path dependent nature of policy. It furthermore adds insight to the processes the drive coalition formation which could be of benefit to both the European politics and game theoretical traditions. However, the study is only an initial step. Future research should seek to test the theory by developing metrics to measure political positions and mathematically model field stabilization in a coalition formation process. While the analysis here is limited to the United States, it would be useful to extend the analysis to other regions to explore the role of political and cultural context. The relationship between field stabilization and democratic function should likewise be further investigated.

With further development the model has significant policy applications. If the conditions of prior policy and coalition formation are adequately understood, the model could be used to predict or project future policy trajectories. The model could also be used to understand current policy dilemmas and to more quickly find the equilibrium or range of equilibriums that will stabilize the field of conflict. This could have a considerable benefit in accelerating the rate of policy development under conditions requiring quick action, i.e. climate change. However, the timing of policy development may be a component of path dependence, and deserves further investigation. This area of inquiry is of interest to and would be of benefit to political scientists, economists, and geographers alike. 
Diagram 1. The policy field of responses to addressing climate change, representing four basic policy options

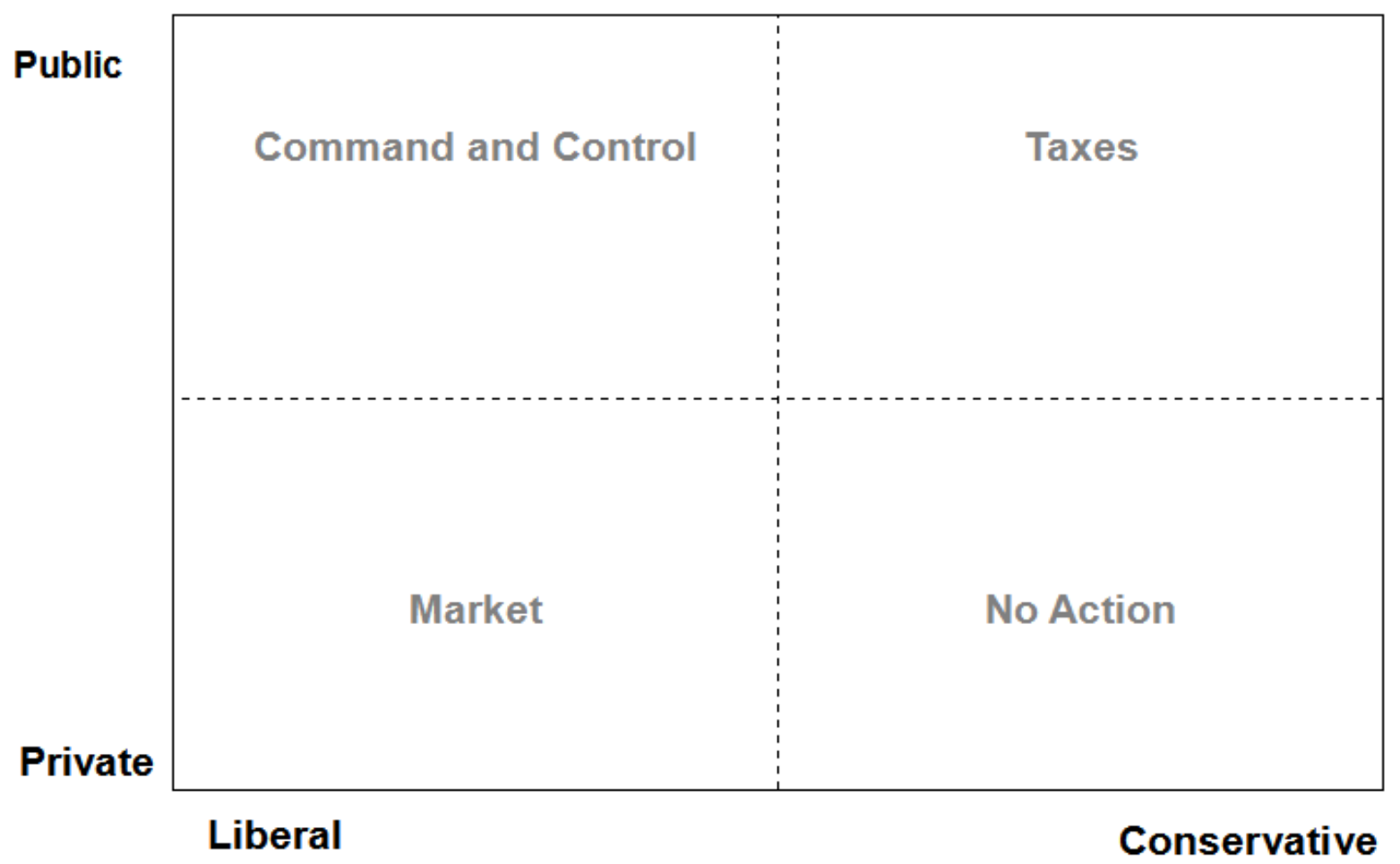

Diagram 2. Initial positioning of organizations in debate over Lieberman-Warner.

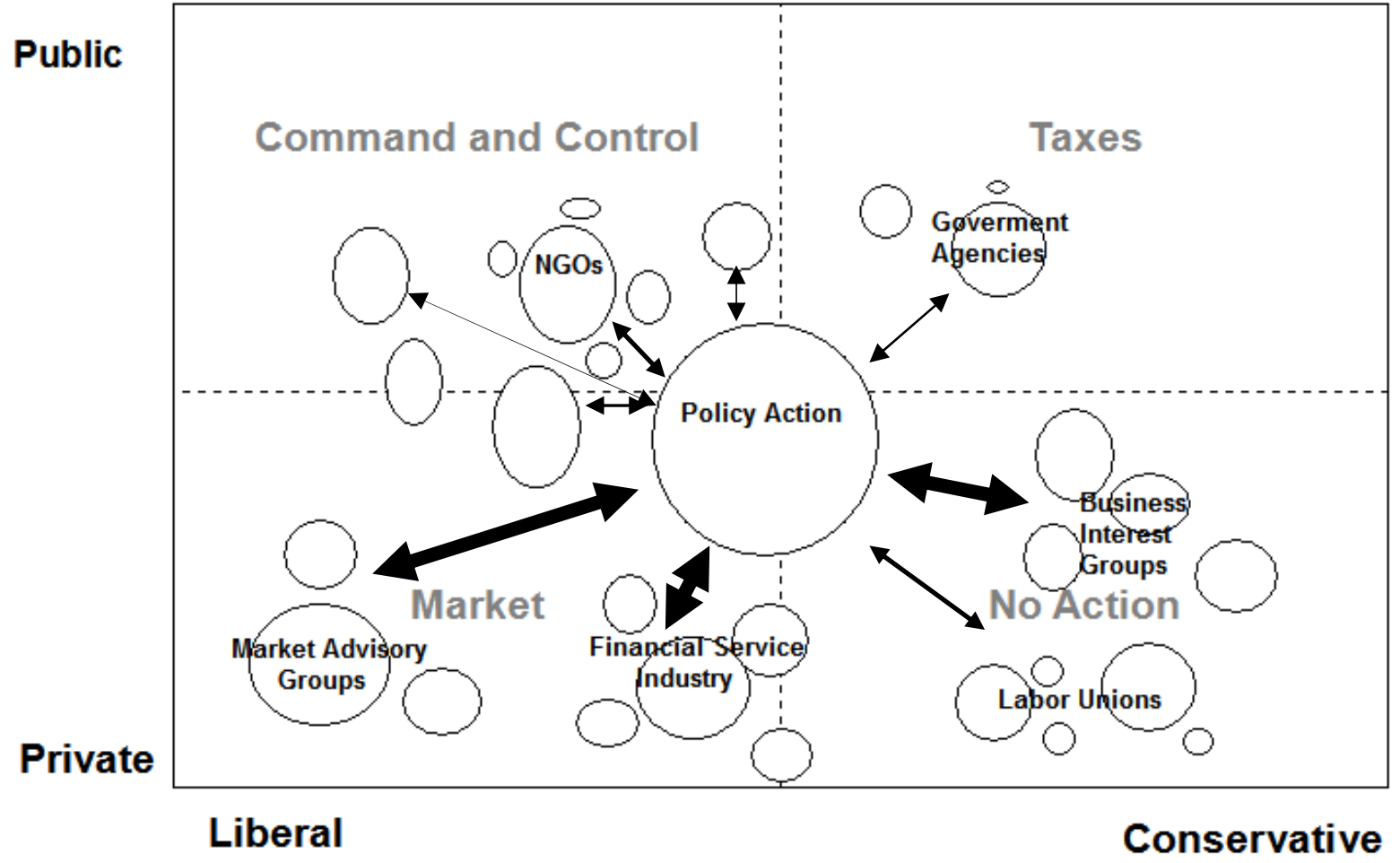


Diagram 3. Movement of the policy response and organizational positioning in the policy field after the first stabilization

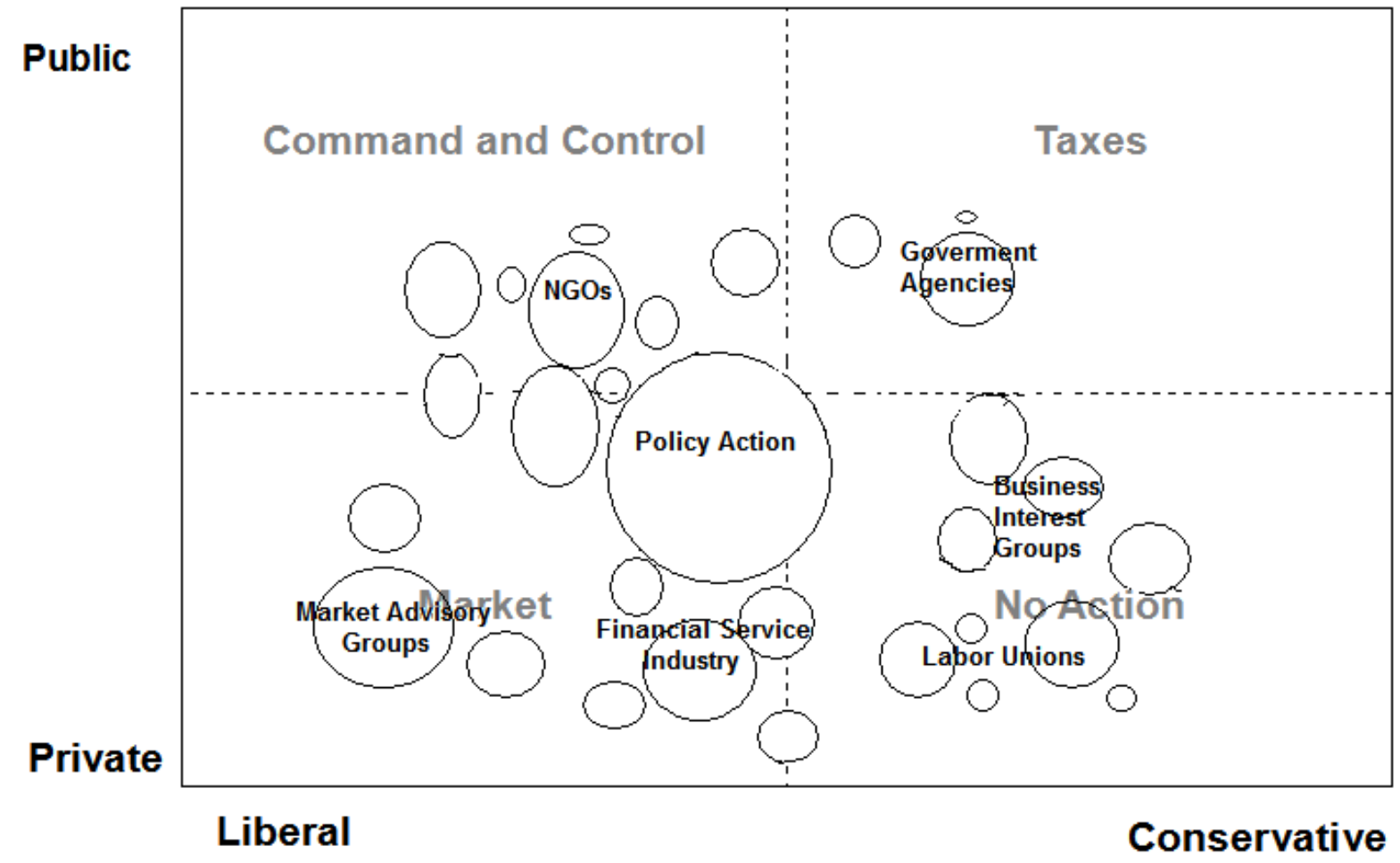

Diagram 4. Path construction: vector representing the final inertia of the policy stabilization after the attempt to pass Lieberman-Warner

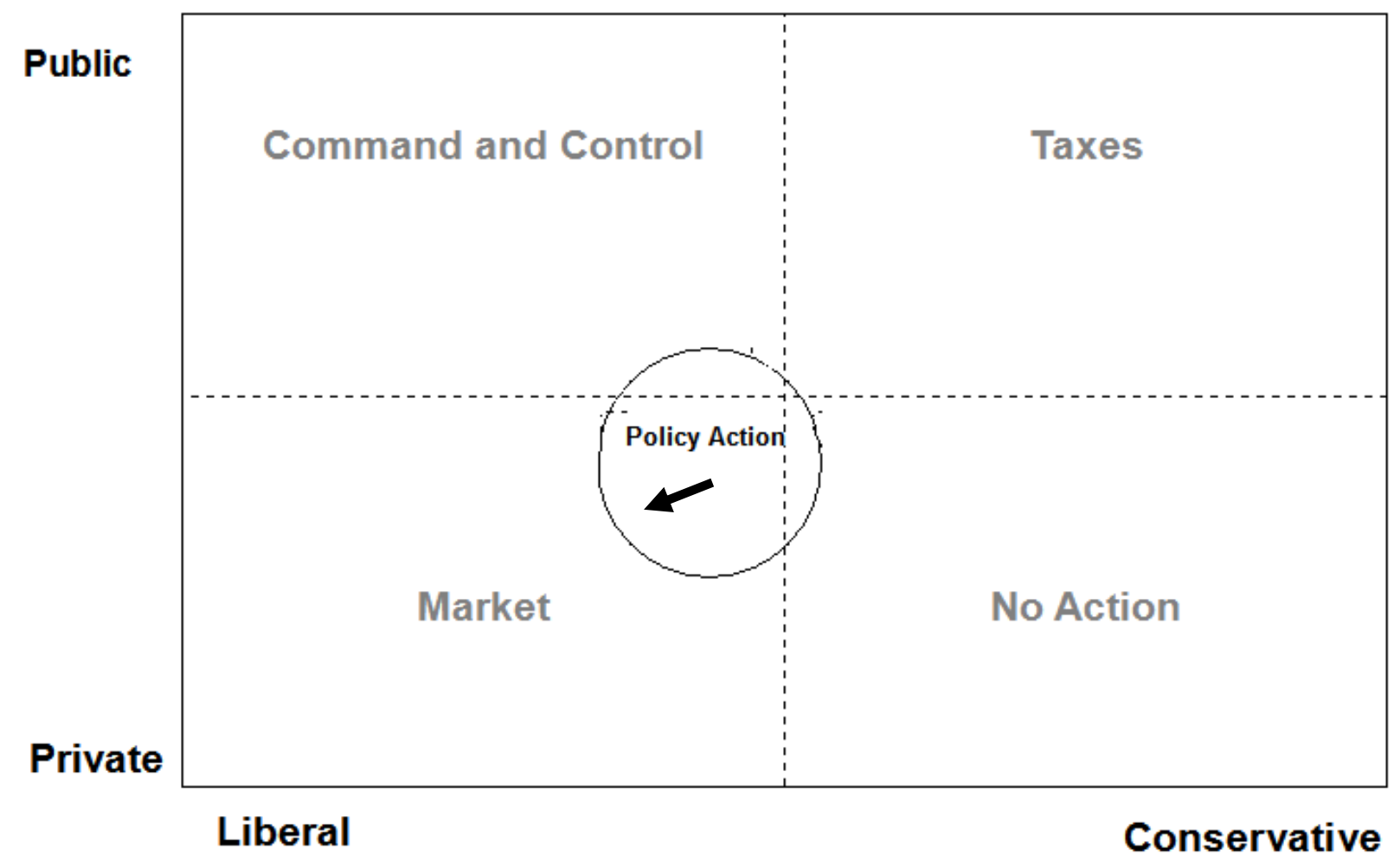


Diagram 5. The policy field with interest groups represented in debate over AB 32

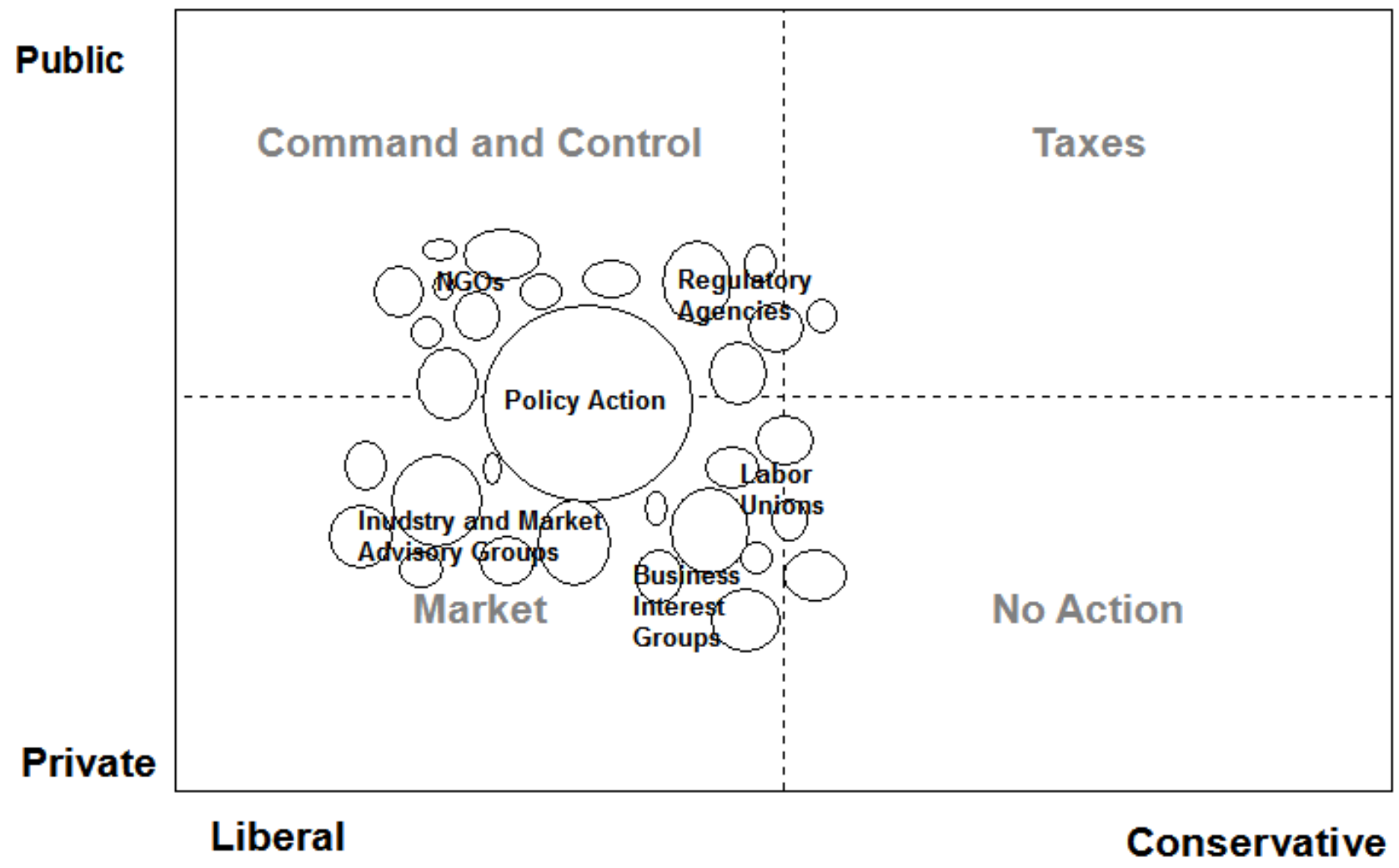




\section{References}

To erase later (Castles \& Mair, 1984)

Acemoglu, D., Egorov, G., \& Sonin, K. (2006). Coalition Formation in Political Games. NBER Working Paper.

Aglietta, M., \& Breton, R. (2001). Financial systems, corporate control and capital accumulation. Economy and Society, 30(4), 433-466.

Bassanini, A. P., \& Dosi, G. (2001). When and how chance and human will can twist the arms of clio: an essay on path dependence in a world of irreversibilities. In R. Garud \& P. Karnøe (Eds.), Path Dependence and Creation (pp. 41-68). London: Lawrence Erlbaum.

BBC. (2009a). Clinton urges stronger China ties. February 21, 2009 [Electronic Version]. British Broadcasting Corporation: Asia Pacific. Retrieved February 23, 2009 from http://news.bbc.co.uk/1/hi/world/asia-pacific/7903026.stm.

BBC. (2009b). Obama Aims for Oil Independence. January 26, 2009 [Electronic Version]. British Broadcasting Corporation: Americas. Retrieved February 10, 2009 from http://news.bbc.co.uk/1/hi/world/americas/7851038.stm.

Berry, J. M. (2003). Validity and Reliability Issues In Elite Interviewing. PS: Political Science and Politics, 35(04), 679-682.

Boyer, R. (2005). How and why capitalisms differ. Economy and Society, 34(4), 509-557.

Budge, I., \& Keman, H. (1990). Parties and democracy : coalition formation and government functioning in twenty states. Oxford: Oxford University Press.

Capoor, K., \& Ambrosi, P. (2008). State and Trends of the Carbon Market, 2007: World Bank Carbon Finance Unit.

CARB. (2009). California's Clean Air Agency Introduction to the Air Resources Board Retrieved February 122009 from http://www.arb.ca.gov/html/brochure/arb.htm

Carr, C., \& Rosembuj, F. (2007). World Bank Experiences in Contracting for Emissions Reductions. Environmental Liability, 2, 114-119.

Castles, F. G., \& Mair, P. (1984). Left-Right Political Scales: Some'Expert'Judgments. European Journal of Political Research, 12(1), 73-88.

CEC. (2009). Welcome to the website of the California Energy Commisssion! Home: About the Commission Retrieved February 122009 from http://www.energy.ca.gov/commission/index.html

Clark, G. L. (1998). Stylized facts and close dialogue: Methodology in economic geography. Annals of the Association of American Geographers, 88(1), 73-87.

Clark, G. L. (2002). London in the European financial services industry: locational advantage and product complementarities. Journal of Economic Geography, 2(4), 433.

Clark, G. L., \& Wojcik, D. (2007). The Geography of Finance : Corporate Governance in a Global Marketplace. Oxford: Oxford University Press.

Coase, R. H. (1968). The problem of social cost. Journal of law and economics. , 3, 1-44.

Colomer, J. M. (Ed.). (2002). Political Institutions in Europe. London: Routledge.

Culver, J. H., \& Syer, J. C. (1988). Power and politics in California (3rd ed.). New York and London: Macmillan; Collier Macmillan.

Dales, J. H. (2002). Pollution, property \& prices : an essay in policy-making and economics. Cheltenham: Edward Elgar. 
David, P. A. (1994). Why are institutions the ‘carriers of history'? Path dependence and the evolution of conventions, organizations and institutions. Structural change and economic dynamics, 5(2), 205-220.

David, P. A. (2007). Path dependence: a foundational concept for historical social science. Cliometrica, 1(2), 91-114.

de Swaan, A. (1973). Coalition Theories and Cabinet Formations: A Study of Formal Theories of Coalition Formation Applied to Nine European Parliaments After 1918: Jossey-Bass.

Ecchia, G., \& Mariotti, M. (1998). Coalition Formation in International Environmental Agreements and the Role of Institutions. European Economic Review, 42, 573-582.

Elgstrom, O., Bjurulf, B., Johansson, J., \& Sannerstedt, A. (2001). Coalitions in European Union Negotiations. Scandinavian Political Studies, 24(2), 111-128.

Finus, M. (2003). New Developments in Coalition Theory. Environmental Policy in an International Perspective.

Fligstein, N. (1996). Markets as Politics: A Political-Cultural Approach to Market Institutions. American Sociological Review, 61(4), 656-673.

Fligstein, N. (2001). The architecture of markets : an economic sociology of twenty-first-century capitalist societies. Princeton, N.J. ; Oxford: Princeton University Press.

Glasmeier, A. (2000). Manufacturing time : global competition in the watch industry, 1795 2000. New York ; London: Guilford Press.

Goldstein, K. (2003). Getting in the Door: Sampling and Completing Elite Interviews. PS: Political Science and Politics, 35(04), 669-672.

Granovetter, M. (1985). Economic Action and Social Structure: The Problem of Embeddedness. American Journal of Sociology, 91(3), 481.

Hamilton, K., Bayon, R., Turner, G., \& Higgins, D. (2007). State of the Voluntary Carbon Markets 2007: Picking Up Steam. EcoSystem Marketplace and New Carbon Finance. Available at http://ecosystemmarketplace. com/documents/acrobat/StateoftheVoluntaryCarbonMarket17July. pdf.

Hanemann, M. (2008). California's New Greenhouse Gas Laws. Review of Environmental Economics and Policy, 2(1), 114.

Hanemann, W. M. (2007). How California Came to Pass AB 32, the Global Warming Solutions Act of 2006. University of California, Berkeley. https://www. law. berkeley. edu/centers/envirolaw/capandtrade/speakers/PDFs/Hanemann\% 20paper. pdf (accessed February 17, 2007).

Hansjürgens, B. (2005). Emissions Trading for Climate Policy: US and European Perspectives: Cambridge University Press.

Hasselknippe, H. (2003). Systems for carbon trading: an overview. Climate Policy, 3(1002), 4357.

Hillman, A. J., \& Hitt, M. A. (1999). Corporate Political Strategy Formulation: A Model Approach, Participation, and Strategy Decision. The Academy of Management review, 24(4), 825-842.

IETA. (2009). About IETA. IETA: Making Markets Work for the Environment Retrieved February 18, 2009 from http://www.ieta.org/ieta/www/pages/index.php?IdSiteTree=2

IPCC., Metz, B., Davidson, O., Bosch, P., Dave, R., \& Meyer, L. (Eds.). (2007). Climate Change 2007: Mitigation: Cambridge University Press, Cambridge, United Kingdom and New York, NY, USA. 
Keman, H. (1997). The politics of problem-solving in postwar democracies. Basingstoke: Macmillan.

Knight, E. R. W. (2008). The Economic Geography of Carbon Market Trading: How Legal Regimes and Environmental Performance Influence Share Performance Under a Carbon Market [Electronic Version]. SSRN Working Papers. Retrieved February 18. 2009 from http://ssrn.com/abstract=1302982

Knox-Hayes, J. (2008). Constructing Carbon Market Spacetime: Implications for NeoModernity. SSRN: http://ssrn.com/paper=1292323

Knox-Hayes, J. (Forthcoming 2009). The Developing Carbon Financial Service Industry: Expertise, Adaptation and Complementarity in London and New York. Journal of Economic Geography.

Kriesi, H., Adam, S., \& Jochum, M. (2006). Comparative analysis of policy networks in Western Europe. Journal of European Public Policy, 13(3), 341-361.

Laver, M., \& Schofield, N. (1998). Multiparty government : the politics of coalition in Europe (Ann Arbor paperback ed.). Ann Arbor, Mich.: University of Michigan Press.

Levy, D. L., \& Egan, D. (2003). A Neo-Gramscian Approach to Corporate Political Strategy: Conflict and Accommodation in the Climate Change Negotiations*. Journal of Management Studies, 40(4), 803-829.

Levy, D. L., \& Newell, P. J. (2005). The Business Of Global Environmental Governance: MIT Press.

Lieberman, J., \& Warner, J. (2007). America's Climate Security Act [Electronic Version]. United States Senate from http://thomas.loc.gov/cgi-bin/query/z?c110:S.3036: Accessed on February 18, 2008.

Lieberman, J., \& Warner, J. (2008). America's Climate Security Act [Electronic Version]. United States Senate from http://thomas.loc.gov/cgi-bin/query/z?c110:S.3036: Accessed on February 18, 2008.

Lipset, S. M. (1963). Political man: the social bases af politics. New York: Doubleday.

Liverman, D. (Forthcoming). Conventions of Climate Change: Constructions of Danger and the Disposession of The Atmosphere. Journal of Historical Geography.

Manza, J., \& Brooks, C. (1999). Social cleavages and political change : voter alignments and U.S. party coalitions. Oxford: Oxford University Press.

Marks, G., \& Diamond, L. J. (Eds.). (1992). Reexamining Democracy: Essays in Honor of Seymour Martin Lipset. London: Sage Publications.

Martin, R., \& Sunley, P. (2006). Path dependence and regional economic evolution. Journal of Economic Geography, 6(4), 395-437.

Mèuller, W. C., \& Strom, K. (1999). Policy, office, or votes? : how political parties in Western Europe make hard decisions. Cambridge: Cambridge University Press.

NRDC. (2009). The Boxer-Lieberman-Warner Climate Security Act Substitute Amendment. NRDC Legislative Fact Sheet, from http://www.nrdc.org/legislation/factsheets/leg_07121101A.pdf. Accessed February 18, 2009

Nugent, N. (1999). The government and politics of the European Union (4th ed.). Basingstoke: Macmillan.

Nuñez, F., \& Pavley, F. (2006). Assembly Bill 32-California Global Warming Solution Act of 2006 [Electronic Version]. California State Assembly from 
http://www.climatechange.ca.gov/publications/legislation/ab_32_bill_20060927_chapter ed.pdf: Accessed on February 19, 2008.

Olsen, J. P. (1991). Political Science and Organization Theory. Parallel Agendas but utual Disregard. In R. M. Czada \& A. Windhoff-Heritier (Eds.), Political Choce, Institutions, Rules and the Limits of Rationality. Frankfurt and Boulder, CO: Campus and Westview.

Pennings, P. (1997). Socioeconomic Problem-Solving between Conflict and Consensus. In H. Keman (Ed.), The politics of problem-solving in postwar democracies. (pp. 68-84). Basingstoke: Macmillan.

Porteous, D. (1999). The Development of Financial Centres:Location, Information, Externalities and Path Dependence. In R. Martin (Ed.), Money and the Sapce Economy (pp. 95-114). Chichester: Wiley.

Quattrone, P. (2006). The Possibility of the Testimony: A Case for Case Study Research. Organization, 13(1), 143.

Riker, W. H. (1962). The theory of political coalitions: Yale University Press New Haven.

Roe, M. J. (2006). Legal origins, politics, and modern stock markets. Harvard Law Review, 120(2), 460-527.

Rosenfeld, A. H. (1999). The Art of Energy Efficiency: Protecting the Environment with Better Technology. Annual Review of Energy and the Environment, 24, 33-82.

Schofield, N. (1986). Existence of a 'structurally stable'equilibrium for a non-collegial voting rule. Public Choice, 51(3), 267-284.

Shepsle, K. A. (1979). Institutional Arrangements and Equilibrium in Multidimensional Voting Models. American Journal of Political Science, 23(1), 27-59.

Spence, D. (1995). Negotiations, coalitions and the resolution of inter-state conflicts. In M. Westlake (Ed.), The Council of the European Union. London: Cartermill.

Stern, N., Peters, S., Bakhshi, V., Bowen, A., Cameron, C., Catovsky, S., et al. (2006). Stern Review: The Economics of Climate Change. HM Treasury, London.

Strauss, A. L., \& Corbin, J. M. (1998). Basics of Qualitative Research: Techniques and Procedures for Developing Grounded Theory: Sage Publications Inc.

US Census Bureau. (2009). Annual Population Estimates 2000 to 2008 [Electronic Version]. National and State Population Estimates from http://www.census.gov/popest/states/NSTann-est.html Accessed on February 19, 2008.

Villaraigosa, A. R. (2007). Mayor Villaraigosa, Mayor Foster, Port Leaders Unite Behind 2008 Ban on Dirty Trucks [Electronic Version]. Press Release from http://mayor.lacity.org/stellent/groups/electedofficials/@myr_ch_contributor/documents/ contributor_web_content/lacity_004622.pdf Accessed on February 19, 2008.

von Beyme, K. (1983). The Political System of the Federal Republic of Germany. Albershot: Gower.

Wallace, H. (1990). Making Multilateral Negotiations Work. In H. Wallace \& W. Wallace (Eds.), The Dynamics of European Integration (pp. 213-228). London and New York.

Wallace, H. (1996). The Institutions of the EU: Experience and Experiments. In H. Wallace \& W. Wallace (Eds.), Policy-Making in the European Union (Vol. 3, pp. 37-68): Oxford University Press.

Warleigh, A. (2000). The hustle: citizenship practice, NGOs and'policy coalitions' in the European Union-the cases of Auto Oil, drinking water and unit pricing. Journal of European Public Policy, 7(2), 229-243. 
Watanabe, R., \& Robinson, G. (2005). The European Union Emissions Trading Scheme (EU ETS). Climate Policy, 5, 10-14.

Woldendorp, J. (1997). Corporatism and socioeconomic conflict-regulation. In H. Keman (Ed.), The politics of problem-solving in postwar democracies. (pp. 43-67). Basingstoke: Macmillan. 